\title{
Status of Academic Librarians in New York State
}

\author{
Marjorie A. Benedict, Jacquelyn A. Gavryck, \\ and Hanan C. Selvin
}

A survey of 188 head librarians in all types of college and university libraries in New York found that all or most of the librarians in 90 percent of the responding libraries are said to have faculty status. Public institutions and two-year colleges had the highest rates. The ACRL Standards for Faculty Status for College and University Librarians tend to define faculty status in the responding libraries, but librarians have acquired more of the responsibilities of faculty status than the traditional rewards.

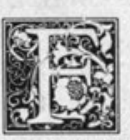

aculty status for academic librarians is as controversial and ambiguous in 1982 as it has been for more than a century. In 1971 the Association of College and Research Libraries (ACRL) adopted its Standards for Faculty Status for College and University Librarians ${ }^{1}$ (hereafter the $A C R L$ Standards). Since then, these standards have become the most widely accepted criteria for defining faculty status for librarians. Some evidence of how closely the realities of librarians' status in libraries across the nation correspond to the $A C R L$ Standards has been collected and published by researchers. ${ }^{2}$ Although the findings from the various surveys are valuable, they are sometimes contradictory. This is partially because of a lack of standardization of survey methodology and analysis of data. What many of the surveys conducted since 1971 have in common, and this one is not an exception, are questions on the criteria outlined in the ACRL Standards.

\section{SURVEY TECHNIQUES}

New York makes a particularly useful subject for a study of librarians' status because it is a major state that has many institutions of postsecondary education. Moreover, almost every conceivable type of institution can be found in New York. This study reflects that diversity.

By means of a postal questionnaire, we queried the head librarians of 264 accredited institutions of higher education in New York, selecting from a directory produced by the New York State Education Department ${ }^{3}$ all libraries that employ at least one full-time librarian. We received usable replies from 188 , or 71 percent. The sample includes four principal types of institutions, representing both the public and private sectors:

- Two-year colleges (57 respondents)

- Four-year colleges, some of which offer master's programs (83 respondents)

- Universities, offering bachelor's, master's, and doctoral programs (24 respondents)

- Graduate/professional schools (24 respondents)

For each case, we collected data on the institution, its library, and the status, including the rights and responsibilities, of

Marjorie A. Benedict is senior assistant librarian, State University of New York at Albany; Jacquelyn A. Gavryck is associate librarian, State University of New York at Albany; and Hanan C. Selvin is professor of sociology, State University of New York at Stony Brook. 
librarians. Our survey, therefore, covers the formal characteristics of the status of librarians in all types of academic libraries in New York as perceived by head librarians. $^{4}$

\section{PATTERNS OF FACULTY STATUS}

As a first step toward conceptualizing the attainment of faculty status, we asked each head librarian the following direct question: "According to the definition used in your institution, do librarians have faculty status?" Table 1 summarizes their replies.

The variation in these replies-from 18 percent reporting that no librarians have faculty status to 65 percent reporting that all librarians have faculty status-probably reflects both the ambiguity of the concept of faculty status and the heterogeneity of the libraries studied.

\section{Sources of Variation between Institutions}

Our analysis suggests that there is considerable variation in the patterns of fac-

\section{TABLE 1}

REPORTED STATUS OF LIBRARIANS IN ALL RESPONDING INSTITUTIONS

\begin{tabular}{lc}
\hline \hline & Percent \\
\hline None have faculty status & 18 \\
Very few have faculty status & 8 \\
About half have faculty status & 0.5 \\
Most have faculty status & 7 \\
All have faculty status & 65 \\
\cline { 2 - 2 } Totals & $98.5^{\star}$ \\
$N=$ & $(188)$ \\
\hline
\end{tabular}

-Does not equal 100 percent because of rounding. ulty status from one institution to another. This variation, however, does not occur at random, but is socially patterned. As an example of such patterning, we shall discuss the ways in which the rate of faculty status is related to (1) the type of institution (two-year colleges, four-year colleges, universities, or graduate/professional schools), and (2) the nature of the institutions' sponsorship or control (public, private church-related, or private independent).

Table 2 shows the status of librarians by type of institution. A pattern clearly emerges. As the academic level in these institutions rises, the incidence of faculty status falls: 79 percent of the two-year colleges, 64 percent of the four-year colleges, 54 percent of the universities, and 50 percent of the graduate/professional schools have indicated that all of their librarians have faculty status. When we combine the two highest positive responses into a single category, "all or most librarians have faculty status," this pattern persists with an even wider gap between the graduate/ professional schools and the other three types of institutions. (See figure 1.)

One possible explanation for this finding rests on the putative prestige of the classroom faculty in these different types of institutions and on the tendency of institutions to be more generous in assigning the responsibilities of faculty status to librarians than they are in granting the rewards. ${ }^{5}$ Because people would probably attribute higher prestige to classroom faculty at graduate-level institutions than to faculty at two-year colleges, according faculty status to librarians in the graduate/ professional institutions would amount to

TABLE 2

STATUS OF LIBRARIANS BY TYPE OF INSTITUTION

\begin{tabular}{|c|c|c|c|c|}
\hline Status of Librarians & $\begin{array}{l}\text { Two-year } \\
\text { Colleges } \\
\text { (Percent) }\end{array}$ & $\begin{array}{c}\text { Four-year } \\
\text { Colleges } \\
\text { (Percent) }\end{array}$ & $\begin{array}{l}\text { Universities } \\
\text { (Percent) }\end{array}$ & $\begin{array}{c}\text { Graduate/ } \\
\text { Professional } \\
\text { Schools } \\
\text { (Percent) } \\
\end{array}$ \\
\hline None have faculty status & 16 & 18 & 17 & 25 \\
\hline Very few have faculty status & 0 & 6 & 21 & 25 \\
\hline About half have faculty status & 0 & 1 & 0 & 0 \\
\hline Most have faculty status & 5 & 11 & 8 & 0 \\
\hline All have faculty status & 79 & 64 & 54 & 50 \\
\hline $\begin{array}{l}\text { Totals } \\
N=\end{array}$ & $\begin{array}{l}100 \\
(57)\end{array}$ & $\begin{array}{l}100 \\
(83)\end{array}$ & $\begin{array}{l}100 \\
(24)\end{array}$ & $\begin{array}{l}100 \\
(24)\end{array}$ \\
\hline
\end{tabular}




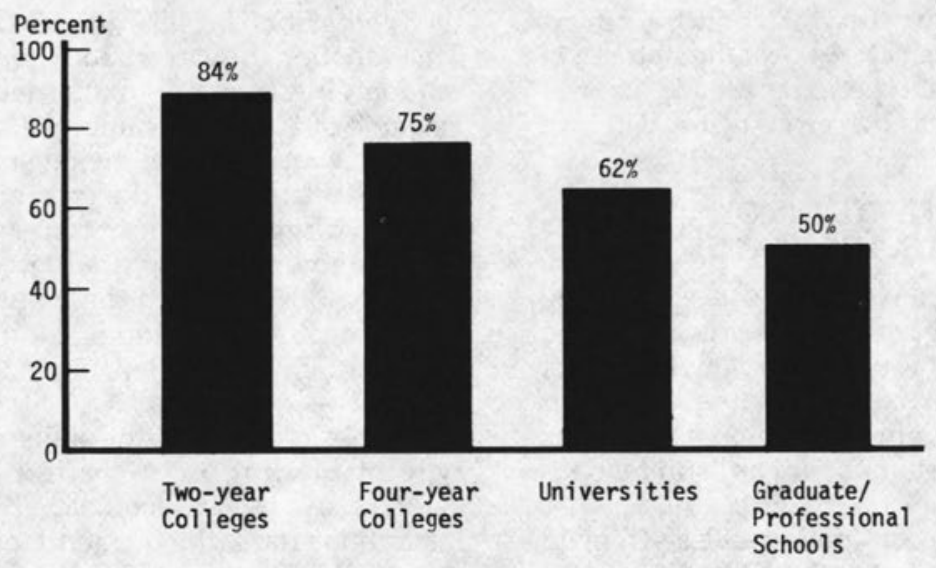

Percent reporting that all or most librarians have faculty status

FIGURE 1

Incidence of Faculty Status by Type of Institution

giving a reward of relatively high value, whereas in the two-year colleges the reward would be of lower value. Other things being equal, high rewards are given less frequently. Another reason may be that the librarians employed in two-year colleges have attained a level of formal education more nearly comparable to that of their classroom colleagues than have the librarians employed in graduate / professional schools. In any event, these two possible explanations would account only in part for this pattern.

We have identified three categories of control or sponsorship of the institutions in this survey: public, private churchrelated, and private independent. Table 3 shows the reported status of librarians for each category. Again combining the two highest responses, public institutions have the highest rate of faculty status, 93 percent, and private independent institutions have the lowest rate, 49 percent. (See figure 2.) Perhaps this is because many of the public institutions have been established in more recent times and have had to conform with newer standards; while in the older, private institutions such evolution is coming about more slowly.

Type of institution and institutional control cannot be studied independently. What appear to be the effects of type of institution are in part the effects of control and vice versa. For example, in table 4 the

TABLE 3

STATUS OF LIBRARIANS BY INSTITUTIONAL CONTROL

\begin{tabular}{|c|c|c|c|}
\hline Status of Librarians & $\begin{array}{l}\text { Public } \\
\text { (Percent) }\end{array}$ & $\begin{array}{l}\text { Institutional Control } \\
\text { Private } \\
\text { Church-Related } \\
\text { (Percent) }\end{array}$ & $\begin{array}{l}\text { Private } \\
\text { Independent } \\
\text { (Percent) }\end{array}$ \\
\hline None have faculty status & 7 & 19 & 31 \\
\hline Very few have faculty status & 0 & 6 & 20 \\
\hline About half have faculty status & 0 & 2 & 0 \\
\hline Most have faculty status & 5 & 9 & 9 \\
\hline All have faculty status & 88 & 64 & 40 \\
\hline $\begin{array}{l}\text { Totals } \\
N=\end{array}$ & $\begin{array}{l}100 \\
(76)\end{array}$ & $\begin{array}{l}100 \\
(47)\end{array}$ & $\begin{array}{l}100 \\
(65)\end{array}$ \\
\hline
\end{tabular}




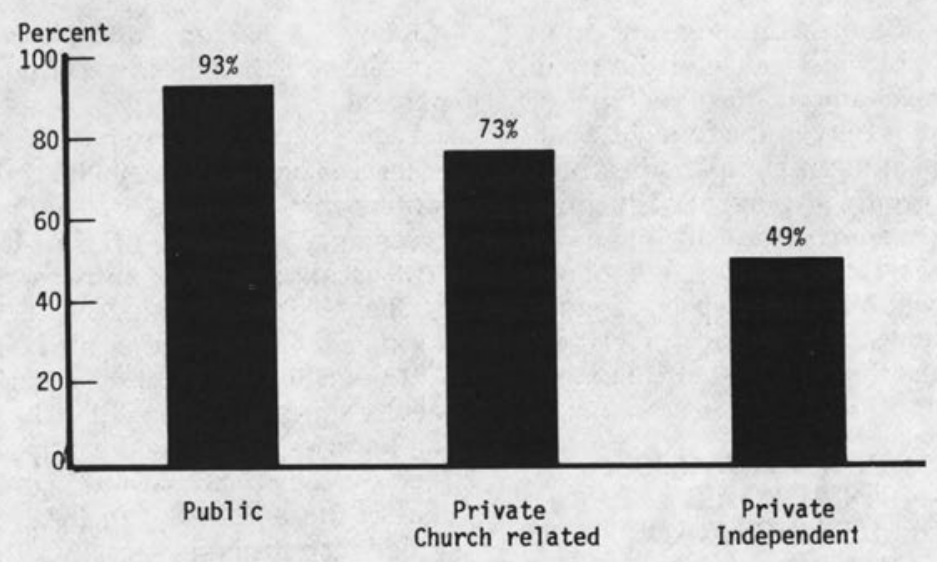

Percent reporting that all or most librarians have faculty status

FIGURE 2

Incidence of Faculty Status by Institutional Control

proportion of respondents from public institutions ranges from 70 percent for twoyear colleges to 17 percent for graduatel professional schools. This strong association between institutional type and control makes it necessary to look at the effects of type of institution on faculty status within each category of control and at the effects of control within each type of institution. (See table 5.)

Because of the small number of cases in several cells of table 5 , we have based the following analysis on only those cells having more than six cases. The effects of type on faculty status appear in the columns. In the first column one can observe that there is little difference in the proportion granting faculty status to all or most librarians among the four types of public institutions; the highest percentage, 100 , is for universities and the lowest percentage, 93 , is for two-year colleges, a difference of only 7 percentage points. The effect is greater within the private independent institutions with a difference of 13 percentage points between the highest, four-year colleges (55 percent), and the lowest, graduate/professional schools (42 percent). The effect of type of institution is the greatest in the private church-related in- stitutions, with 27 percentage points difference between the four-year colleges (77 percent) and the graduate/professional schools (50 percent).

TABLE 4

PUBLIC CONTROL BY TYPE OF INSTITUTION

\begin{tabular}{lcc}
\hline \hline $\begin{array}{l}\text { Type of } \\
\text { Institution }\end{array}$ & $\begin{array}{c}\text { Percent } \\
\text { Public } \\
\text { Institutions }\end{array}$ & $\begin{array}{c}\text { (Number } \\
\text { of Cases) }\end{array}$ \\
\hline Two-year Colleges & 70 & $(57)$ \\
Four-Year Colleges & 29 & $(83)$ \\
Universities & 33 & $(24)$ \\
$\begin{array}{l}\text { Graduate/Professional } \\
\text { Schools }\end{array}$ & 17 & $(24)$ \\
\hline
\end{tabular}

TABLE 5

FACULTY STATUS BY INSTITUTIONAL TYPE AND CONTROL*

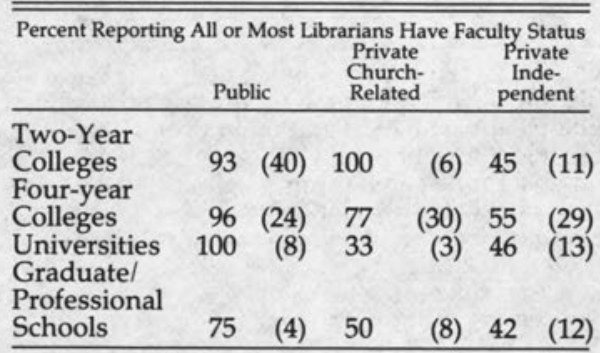

-Numbers of cases are in parentheses. 
The effects of control on status appear in the rows of table 5 . Because of the small numbers of cases among the other types of institutions, it is only in the four-year colleges that a meaningful comparison is possible. In this group, 96 percent of the public colleges report that all or most librarians have faculty status, compared with 55 percent among the private independent colleges, a difference of 41 percentage points, the strongest effect in this table.

\section{THE ACRL STANDARDS AND NEW YORK ACADEMIC LIBRARIANS}

The ACRL Standards outline nine areas of rights and responsibilities for academic librarians. We studied criteria drawn from several of these areas, concentrating on those we judged to be most appropriate for a self-administered questionnaire to be completed by concerned, but busy, library administrators. The questions based on these criteria appear in appendix A.

\section{Rights and Responsibilities}

Most of the ACRL criteria used for this survey can be considered to be rights, although only three of them represent unequivocal rights: academic-year appointment, professorial titles, and tenure. (We did not include another unequivocal right, equality of compensation, in this survey.) Table 6 shows the incidence of favorable replies to questions on the criteria that we perceive as rights. In the 188 responding libraries, eligibility to serve on the campus governance body has the highest fre- quency, 76 percent, and academic-year appointment has the lowest frequency, 16 percent.

We recognize only two of the surveyed criteria as pure responsibilities: the expectations that librarians hold graduate degrees apart from the MLS or its equivalent, and that they show a record of publishable scholarship. (Neither of these is explicitly stated in the ACRL Standards.) Although all or most of the librarians have faculty status in 72 percent of the responding libraries, academic-year appointment is enjoyed by the librarians in only 16 percent of these libraries. In the category of added responsibilities, on the other hand, the percentages are considerably higher. When it comes to promotion and tenure decisions, 48 percent of the responding institutions attach more than a little importance to librarians' holding a graduate degree in addition to a master's degree in library science, and 41 percent attach more than a little importance to the librarians' having a record of publishable scholarship. Looking at just the 137 libraries in which faculty status was reported for all or most of the librarians, we found that 22 percent reported academic-year appointments, an increase of only 6 percentage points over the entire sample. At the same time, among these 137 institutions the percentages that affirm the importance of more than one graduate degree, 66 percent, and publishing activity, 56 percent, for promotion and tenure, rise 18 and 15 percentage points, respectively. Our analysis shows a general pattern: librarians in the responding institutions are more

TABLE 6

FAVORABLE RESPONSES REGARDING LIBRARIANS' ACADEMIC RIGHTS IN ALL RESPONDING INSTITUTIONS*

\begin{tabular}{lc}
\hline \hline Short Title & Percent \\
\hline Eligible to serve on campus governance body & 76 \\
Eligible for released time for professional activities & 68 \\
Eligible for sabbatical and other professional leaves & 64 \\
Eligible for tenure & 58 \\
Eligible for research funds & 55 \\
Peer review for promotion & 46 \\
Eligible for campus-wide promotion and tenure review body & 46 \\
Professorial titles & 30 \\
Released time for research & 20 \\
Academic-year appointment & 16 \\
\hline
\end{tabular}

*Includes only unequivocal responses. 
likely to have the added responsibilities associated with faculty status than the rights traditionally accorded to the classroom faculty.

\section{Effects of Negatively \\ Integrated Norms Associated with Faculty Status}

The ACRL Standards are a set of norms that may be adopted in whole or in part by libraries. Two or more norms are positively integrated if conforming to one makes it easier for most people to conform to the other(s). Similarly, norms are negatively integrated if conforming to one makes it more difficult to conform to the other(s). For example, being active in research is more difficult for librarians than for classroom faculty because norms relating to faculty status are likely to be negatively integrated in libraries. Eight months of scheduled classroom teaching are generally required of instructional faculty, while librarians are usually expected to engage in scheduled activities such as cataloging or reference work for eleven months of the year. Additionally, many librarians may find themselves in situations where tenured peers had become used to a system that did not concern itself with the complexities of faculty status. Under these circumstances, peer review by librarians makes it difficult for librarians to obtain recognition from peers for scholarly activity. Moreover, the problem becomes acute when nominations for promotion and tenure are reviewed by the campus-wide promotion and tenure body, which may interpret standards differently in making its recommendations than do the librarians who review the candidates.

Discrepancies such as these can lead to a considerable amount of role strain among librarians having faculty status. Because positively integrated norms tend to persist and negatively integrated norms do not, evasive behavior appears in situations where norms are negatively integrated. Increased rates of absenteeism and turnover in personnel may result as librarians attempt to cope with the often conflicting requirements imposed on them by faculty status. In situations where strain is pro- duced by the negative integration of institutionalized norms, the affected individuals and groups have been known to make efforts to relieve the pressures by what Robert K. Merton calls institutionalized evasions of institutional norms. ${ }^{6}$ In the present case, one such conceivable evasion by librarians and campus-wide review committees might be a redefinition of what constitutes scholarly research for librarians, in effect, a separate set of standards.

The inconsistencies and resulting strain for librarian faculty members who have to meet stringent requirements for retention, promotion, and tenure without the concomitant rewards enjoyed by classroom faculty members will continue to provide the ingredients for dissatisfaction with the realities of faculty status among academic librarians. Librarians appear to be divided in their opinions about how to ameliorate the situation. Some prefer to renounce faculty status; others favor continuing to strive for full recognition as faculty members.

\section{Intercorrelation}

\section{of the ACRL Standards}

By means of a factor analysis, a statistical procedure, we have discovered that a majority of the ACRL criteria used in our survey tend to occur together in the responding libraries. That is, there is a tendency for institutions that accord faculty status, in general terms, to all or most of their librarians, to meet a good number of the specific criteria of the ACRL Standards as well.

For the factor analysis, we selected from the ACRL Standards the eight criteria that had the highest rate of response. Five of these criteria showed high intercorrelation. The criterion having the highest correlation with the others was the incidence of reported faculty status; the other four were: eligibility for the campus governance body, released time for professional activities, eligibility for sabbatical and other (long-term) professional leaves, and eligibility for released time for research. The three variables that were not highly correlated with the other five were: eligibility for tenure, professorial titles, and 
academic-year appointment. This statistical relation can be interpreted as evidence that the ACRL Standards are important in empirically defining faculty status for librarians. Consistent with our earlier findings, it appears that the rewards of faculty status are slower in coming than are the responsibilities. One can predict that this tendency is likely to continue in this period of shrinking resources.

\section{CONCLUSIONS AND IMPLICATIONS FOR THE PROFESSION}

This survey has shown that faculty status is the rule in a majority of college and university libraries in the state of New York, particularly in the public systems of the City University of New York and the State University of New York. Although some librarians are enjoying rights, such as academic-year appointment, tenure, and professorial titles, the scales are clearly tipped in the direction of librarians' having the increased responsibilities of faculty status.

Not all of the benefits of faculty status accrue to librarians as individuals. Indeed, some things that represent costs borne by individual librarians, such as increased re- sponsibilities, should result in collective benefits to the profession over the long term.

We have found that nearly all of the librarians employed in the responding libraries hold a graduate degree in library science. More than a third hold an additional graduate degree. Although we don't have comparable past figures on the formal education of New York's academic librarians with which to compare these percentages, our reading ${ }^{7}$ and a 1975 SUNY survey ${ }^{8}$ suggest that today's academic librarians show a higher level of formal education than their predecessors did. Scholarly activity should also contribute to the upgrading of the profession and to bringing librarians closer to the faculty model. Librarians employed in libraries that require scholarly production will become more proficient in doing research and writing, and librarians who enjoy these activities will tend to seek employment in academic libraries where librarians have faculty status. If the levels of both formal education and scholarly activity continue to rise, academic librarianship should benefit in both tangible and intangible ways.

\section{REFERENCES}

1. Association of College and Research Libraries, Committee on Academic Status, Faculty Status for Academic Librarians: A History and Policy Statements (Chicago: American Library Assn., 1975), p.31-34.

2. Some studies that have been done during the past five years are: American Library Association, Association of College and Research Libraries, Academic Status Survey (Chicago: The Association, 1981); Greg W. Byerly, "The Faculty Status of Academic Librarians in Ohio," College \& Research Libraries 41:422-29 (Sept. 1980); Russ Davidson and others, "Faculty Status for Librarians in the Rocky Mountain Region: A Review and Analysis," College \& Research Libraries 42:203-13 (May 1981); Ronald F. Dow, "Academic Librarians: A Survey of Benefits and Responsibilities," College E Research Libraries 38:218-20 (May 1977); JoAnne Hawkins and others, The Status of Status: The Status of Librarians in Texas Academic Libraries (Austin: University of Texas at Austin Libraries, 1978), ED 178 042; Prabha Sharma, "A Survey of Academic Librarians and Their Opinions Related to NineMonth Contracts and Academic Status Configurations in Alabama, Georgia, and Mississippi," College \& Research Libraries 42:561-70 (Nov. 1981).

3. E. J. Josey and Alice L. Britenbaker, eds., A Directory of College and University Libraries in New York State (11th ed.; Albany, N.Y.: The University of the State of New York, State Education Department, 1977).

4. Although many survey researchers employ tests of statistical significance to indicate the findings that deserve the most attention, we believe that they cannot serve this function in research of this kind. See Hanan C. Selvin and Stephen R. Finch, "Methods of Survey Analysis," in William H. Kruskal and Judith M. Tanur, eds., International Encyclopedia of Statistics (New York: Free Press, 1978). 
5. See Mary Biggs, "Sources of Tension and Conflict between Librarians and Faculty," Journal of Higher Education 52:182-201 (Mar.-Apr. 1981); R. Dean Galloway, "Status or Stasis: Academic Librarians 10 Years Later," American Libraries 10:349-52 (June 1979); Jacquelyn A. Gavryck, "The SUNY Librarians' Faculty Status Game," Journal of Academic Librarianship 1:11-13 (July 1975).

6. Robert K. Merton, Preface to Lawyers and Matrimonial Cases by Hubert O'Gorman (New York: Free Press, 1963), p.ix-xi.

7. Galloway, "Status or Stasis," p.349-50.

8. Gavryck, "The SUNY Librarians' Faculty Status Game," p.13.

\section{APPENDIX A: QUESTIONS BASED ON ACRL STANDARDS}

1. According to the definition used in your institution, do librarians have "faculty status"?

2. What titles do the librarians have?

3. Are full-time librarians eligible for tenure?

4. When a librarian is being considered for tenure, is there a formal process of peer review by librarians?

5. When a librarian is being considered for promotion, is there a formal process of peer review by librarians?

6. In current promotion and tenure cases, how much importance is attached to librarians' holding a graduate degree in addition to the MLS?

7. When it comes to promotion and tenure, how important is it that librarians show a record of publishable scholarship?

8. If your institution has a campus-wide promotion and tenure body, are librarians eligible to serve on it?

9. Are librarians eligible to serve on the campus "governance" body (e.g., faculty senate, faculty assembly) on the same basis as are other faculty members?

10. Are librarians eligible for sabbatical and other professional leaves on the same basis as are other faculty members?

11. Are research funds from your institution available to librarians on the same basis as to other faculty members?

12. Does your institution have a policy of granting time off with pay during working hours for librarians to conduct research?

13. Does your institution have a policy of granting time off with pay during working hours for librarians to engage in professional activities such as course work, workshops, conferences, and the like?

14. Please indicate the length of the work year. 